\title{
Kanıta Dayalı Bir Psikiyatrik Rehabilitasyon Uygulaması: Hastalık Yönetimi ve İyileşme
}

\section{An Evidence-Based Psychiatric Rehabilitation Implementation: Illness Management and Recovery}

\author{
Rüveyda Yüksel '(D), Hülya Arslantaş' (DD
}

\section{$\ddot{0} z$}

Hastalık Yönetimi ve İyileşme (HYi) iyileşme odaklı yaklaşımı temel alan bir program olarak tasarlanmış müfredat tabanlı bir psikiyatrik rehabilitasyon uygulamasıdır. Son yıllarda iyileşme kavramına ilişkin yapılan tanımlamaların klinik iyileşme ve kişisel iyileşme olmak üzere iki şekilde ele alındığı görülmektedir. 2002 yılında ABD'de ruh sağlı̆ı hizmet sunumunun geliştirilmesi için kurulan komisyon ruhsal sağlık sisteminin kapsamlı bir dönüşüm yapması gerektiği yönünde bir çağrıda bulunmuştur. Bu dönüşümün bir parçası olarak komisyon; ruh sağlğı uzmanlarının tedavi konusunda geleneksel, hiyerarşik karar vermektense hasta ve ruh sağlğı profesyonelleri ile hastanın ruh sağlığı tedavisi ile ilgili işbirliğine dayalı karar vermesine doğru bir geçiş önermiştir. Ayrıca, ruhsal hastalı̆ı̆ tedavisi için kanıta dayalı uygulamalara erişimin geliştirilmesinin önemine vurgu yapmışııı. Hastalık Yönetimi ve lyileşme Programı (HYiP), bireylere psikiyatrik bozukluklarını nasıl yöneteceklerini öğretmek için ampirik olarak desteklenen yöntemleri içeren bir müdahale programı olarak geliştirilmiş ve standartlaştırılııstır. HYiP kronik ruhsal hastalığı olan bireylere hastalık yönetiminin öğretilmesi üzerine yapılan araştırmaların kapsamlı bir incelemesinden yola çıkarak geliştirilmiştir. Kontrollü 40 çalışmanın gözden geçirilmesiyle hastalık yönetiminin geliştirilmesi için ampirik olarak desteklenen beş yöntem/strateji tanımlanmıştır. Bunlar: psikiyatrik bozukluklar ve tedavisi hakkında psikoeğitim, ilaç uyumunu artırmada bilişsel-davranış̧ı yaklaşıılar, nüksleri önleme eğitimi, baş etme becerileri eğitimi ve sosyal desteği geliştirmek için sosyal beceri eğitimidir. Bu makalede hastalık yönetimi ve iyileşme odaklı programın ortaya çıkısı, programın işleyişi ve hastalık yönetimi ve iyileşme ile ilgili araş̧ırma örneklerinden söz edilecektir. Derlemenin ülkemizde Hastalık Yönetimi ve İyileşme Programının ruh sağliğı hizmetleri kapsamında uygulanması ve yürütülmesine yol gösterici katkı sağlaması düşünülmektedir.

Anahtar sözcükler: Kanıta dayalı uygulama, psikiyatrik rehabilitasyon, hastalık yönetimi ve iyileşme

\begin{abstract}
Illness Management and Recovery (IMR) is a curriculum based psychiatric rehabilitation intervention which is designed as a program on the basis of a recovery-oriented approach. In recent years, the definitions suggested on the term, recovery, has been seen to be discussed in two ways; clinical recovery and personal recovery. The committee constituted with the aim of developing the mental health service provision in the USA in 2002, issued a call for the necessity for the mental health system's comprehensive transformation. As a part of this transformation, the committee suggested a move towards mental health specialists' making decisions related to patient's mental health treatment in a collaboration with the mental health professionals rather than making conventional, hierarchical decisions. The significance of providing access to evidence-based applications for the treatment of mental illnesses was also stressed. Illness Management and Recovery (IMR) was developed and standardized as a treatment program which comprises empirically supported methods in order to train individuals how to manage their psychiatric disorders. IMR was developed on the basis of an extensive investigation of the researches upon teaching illness management to individuals with chronical mental illnesses. Having reviewed 40 controlled studies, in order to develop illness management, five empirically supported methods/strategies were determined. These are psychoeducation on psychiatric disorders and their treatments, cognitive behavioral approaches on drug compliance, training of preventing relapses, coping skills, and social skills training for developing social support. In this review, the birth of illness management and recovery-oriented program, the process of the program, and research related to illness management and recovery will be depicted. It is expected that the review will instructively contribute to practice and execution of IIIness Management and Recovery Program within the scope of mental health services in Turkey.
\end{abstract}

Keywords: Evidence-based practice, psychiatric rehabilitation, illness management and recovery

'Aydın Adnan Menderes Üniversitesi, Aydın, Türkiye

$凶$ Rüveyda Yüksel, Aydın Adnan Menderes Üniversitesi Hemşirelik Fakültesi, Ruh Sağlığı ve Hastalıkları Hemşireliği Anabilim

Dalı, Aydın, Türkiye

ruveyda.yuksel@adu.edu.tr|0000-0002-5997-4155

Geliş tarihi/Received: 28.09.2020 | Kabul tarihi/Accepted: 24.11.2020 |Çevrimiçi yayın/Published online: 03.06.2021 
IYYILEŞME kavramı ruh sağlığı açısından oldukça önemli bir kavram olmasına rağmen sınırlarının çizilmesinin de bir o kadar güç olduğu bir alandır. Bu durum son yıllarda ruh sağlığı alanında "iyileşme" kavramı üzerinde yapilan tartışmaların artı̧̧ına yol açmıştır. İyileşme kavramına ilişkin yapılan tanımlamaların klinik iyileşme ve kişisel iyileşme ayrımını beraberinde getirdiği görülmektedir. Klinik iyileşme; ruh sağlğ̆1 uzmanları tarafindan semptomların azalması veya kesilmesi (cessation) ve "sosyal işleyişin geri kazanılması" şeklinde tanımlanırken kişisel iyileşme; tedavi görmekte olan birey tarafindan tanımlanan ve kişisel gelişim, iyileşme ve kendini belirlemeyi (self-determination) kapsayan devam etmekte olan holistik bir süreci ifade eder (Slade 2009).

İyileşme bilinen en genel tanımıyla kişinin tutumları, değerleri, duyguları, hedefleri, becerileri ve/veya rollerindeki son derece kişisel, eşsiz bir değişim süreci olarak tanımlanmakta ve ruhsal hastalığın yıkıcı etkilerinin ötesinde büyüyen yeni anlam ve amaç geliştirmeyi içermektedir (Anthony 1993). Leamy ve arkadaşları (2011) iyileşmeyi hayatla bağlantıda olma, umut ve geleceğe ilişkin iyimserlik, kimlik, yaşamı anlamlandırma ve güçlendirme olmak üzere beş kategoride ele almaktadır. "İyileşme" semptomların hafiflemesi ve işlevsellikte düzelmenin klinik kriterler tarafindan tanımlandığı bir sonuçtan ziyade örneğin kişinin kalıcı bir psikotik bozukluğa rağmen ve bu bozuklukla nasıl yaşayacağını öğrenme sürecidir (Davidson 2010).

"İyileşme odaklı uygulama" ise, kişisel kararlılık ve kişisel bakım ilkelerini içeren ruh sağlığı bakım yaklaşımını tanımlamaktadır (Anthony 1993). İyileşme odaklı uygulama umut, toplumsal katılım, kişisel hedef belirleme ve özyönetime vurgu yapmaktadır. İyileşme odaklı uygulamada ruh sağlığı hizmeti alan kişilerle ruh sağlı̆̆ı profesyonelleri arasında rehberlik ya da ortaklık ilişkisi ön plandadır. Bu ilişkide ruh sağlığı hizmeti almakta olan bireyler yaşamları ve deneyimleri konusunda, ruh sağlığı profesyonelleri ise mevcut tedavi hizmetleri konusunda uzman olarak kabul edilirler (Victorian Government Department of Health 2011). Ruh sağlığı hizmeti sunumunda iyileşme odaklı yaklaşımın amacı, ruhsal hastalığın devam eden semptomlarının olup olmadığına bakılmaksızın kişilerin anlamlı ve tatmin edici bir yaşam ve kişisel kimlik oluşturmalarını ve sürdürmelerini desteklemektir (Shepherd ve ark. 2008). Bu makalede hastalık yönetimi ve iyileşme odaklı programının ortaya çıkı̧̧ı, programın işleyişi ve hastalık yönetimi ve iyileşme ile ilgili araştırma örneklerinden söz edilerek araştırma sonuçları tartı̧̧ılmıştır.

\section{Psikiyatrik rehabilitasyon}

Modern psikiyatrik anlayış, ruhsal hastayı olabildiğince ayaktan ve yaşama ortamı içinde izlemeyi, toplumsal işlevlerini yerine getirebileceği en üst düzeye çıkarmayı hedeflemektedir. Toplum ruh sağllğı hizmetleri kapsamında yer alan psikiyatrik rehabilitasyon, ruhsal hastalığı olan insanların toplumda başarılı bir şekilde yaşamaları ve yaşam kalitelerini artırmaları için gereken tüm hizmetleri içeren bir kavramdır (Pektaş ve Çam 2002). Psikiyatrik rehabilitasyon, tıpkı fiziksel rehabilitasyon gibi, ruhsal hastalıkları nedeniyle bireylerde meydana gelen olumsuz yaşantıları ve temel yaşam becerilerini etkileyen kısttlılıları ortadan kaldırmayı veya azaltmayı sağlar (Wallace 1993). Psikiyatrik 
rehabilitasyonun amacı; ruhsal bakımdan hastalığı olan bireylerin toplumsal, mesleksel, eğitsel ve aile içindeki rollerini hiç değilse profesyonel yardım altında başarabilmelerini sağlamak için toplumsal destek sağlamak ve beceri geliştirmektir (Liberman ve ark. 2000, Göka 2001).

Psikiyatrik rehabilitasyon, ciddi ruhsal hastalığı olup, tedavi edilmiş insanlara kendi toplumlarında yaşamak, öğrenmek ve çalışmak için yeni olanaklar sağlama gereksiniminden doğmuştur. Psikiyatrik rehabilitasyon programları, psikiyatri hastanesinden taburcu olan hastalara bağımsız olarak yaşamalarını amaçlayacak şekilde, ihtiyaç duyulan becerileri kazanmalarına ve çevresel kaynakları kullanmalarına yardımcı olan bir hizmettir (Sundeen 1998). Psikiyatrik rehabilitasyonda üç temel girişim kullanılır. Bunlar: Bireyin gücünü ve potansiyelini geliştirme, yaşam becerilerini öğretme ve çevre desteklerini artırmadır (Sundeen 1998, Öztürk ve Uluşahin 2018). Bireyin hastalığa karşı olan duyarlılığını azaltmak ve stresler karşısındaki dayanıklılığını artırmak için psikiyatrik rehabilitasyon çalışmaları üç eksenli yaklaşımı temel kabul eder. Bunlar: Kişiye sıkıntı vermeyecek, ikincil özür oluşmasına yol açmayacak, günlük yaşamını etkilemeyecek şekilde uygun farmakolojik tedavinin seçimi ve sürdürülmesi, kişinin bireysel ve toplumsal yaşamını kolaylaştıracak, engelleri aşmasını sağlayacak şekilde becerilerle donanmasının sağlanması, toplumsal desteklerin kişinin sağlıklı yaşamını sürdürmesini kolaylaştıracak şekilde düzenlenmesidir (Y1ldız 2004). Psikiyatrik rehabilitasyonda görev alan sağlık profesyonelleri; semptomlara değil, sağlıklı olmaya, erişkin-erişkin ilişkisi içerisinde ve doğal ortamda bakım vermeye, kişinin yeteneklerinin, yeterliliklerinin ve fonksiyonel davranışlarının geliştirilmesine, sorunların çözülmesinde hastayla birlikte kararlar almaya odaklanmalıdırlar. Ayrıca hastanın güçlü yanlarının kuvvetlendirilmesi ve hastanın kendine yardımı üzerinde durmalı ve hastanın çevresel kaynaklarını geliştirerek ve hastanın pozitif beklentilerini artırmalıdırlar (Sundeen 1998, Bilge ve Çam 2002).

\section{Hastalık yönetimi ve iyileşme programının doğuşu}

ABD'de 2002 yılında ruh sağlığı hizmet sunumunun geliştirilmesi için kurulan komisyon 2003 yılında meşru bir tedavi amacı olarak iyileşme vizyonunun rehberliğinde ruhsal sağlık sisteminin kapsamlı bir dönüşüm yapması gerektiği yönünde bir çağrıda bulunmuştur. $\mathrm{Bu}$ dönüşümün bir parçası olarak komisyon; ruh sağlığı uzmanlarının tedavi konusunda geleneksel, hiyerarşik karar vermektense hasta ve ruh sağlığı profesyonelleri ile hastanın ruh sağllğ̆ tedavisi ile ilgili işbirliğine dayalı karar vermesine doğru bir geçiş önermiştir. Ayrıca, ruhsal hastalığın tedavisi için kanıta dayalı uygulamalara erişimin geliştirilmesinin önemine vurgu yapmıştır (New Freedom Commission 2003). Komisyonun önerileriyle eş zamanlı olarak, Hastalık Yönetimi ve İyileşme Programı (HYİP), bireylere psikiyatrik bozukluklarını nasıl yöneteceklerini öğretmek için ampirik olarak desteklenen yöntemleri içeren bir müdahale programı olarak geliştirilmiş ve standartlaştırılmıştır (Gingerich ve Mueser 2005).

Hastalık Yönetimi ve İyileşme Programı kronik ruhsal hastalığı olan bireylere hastalık yönetiminin öğretilmesi üzerine yapılan araştırmaların kapsamlı bir incelemesinden yola 
çıkılarak geliştirilmiştir (Mueser ve ark. 2002). Hastalık yönetiminin geliştirilmesi için 40 kontrollü çalışma gözden geçirilerek ampirik olarak desteklenen beş yöntem/strateji tanımlanmıştır. Bunlar: Psikiyatrik bozukluklar ve tedavisi hakkında psikoeğitim, ilaç uyumunu artırmada bilişsel-davranış̧ı yaklaşımlar, nüksleri önleme eğitimi, baş etme becerileri eğitimi ve sosyal desteği geliştirmek için sosyal beceri eğitimidir (Gingerich ve Mueser 2010). İncelenen 40 kontrollü çalışmada yer alan (psikoeğitim, bilişsel davranışçı yaklaşımlar, psikoeğitim, başetme becerileri ve sosyal beceri eğitimi) yöntemlerin hiçbiri hepsini tek bir müdahalede birleştirmemiştir. HYİ, hastalık yönetimini geliştirmek için ampirik olarak desteklenen bu yöntemlerin tümünü birleştirerek tutarlı tek bir programa entegre etmek için ortaya çıkmıştır (Mueser ve ark. 2013).

Hastalık Yönetimi ve İyileşme Programı geliştirildikten sonra iki kez revize edilerek son olarak üçüncü versiyonu oluşturulmuştur (Mueser ve ark. 2002, Gingerich ve Mueser 2005, Mueser ve ark. 2006, Gingerich ve Mueser 2010). Makalenin ilerleyen bölümlerinde HYİ’'nin üçüncü versiyonundan açımlanarak söz edilecektir.

Hastalık Yönetimi ve İyileşme Programı 2000 ve 2002 yılları arasında Ulusal Uygulama Tüzüğü Kanıtlarına Dayalı Uygulamalar Projesinin bir parçası olarak geliştirilmiştir. HYİ’nin kullanımını teşvik etmek için program bir "Uygulama Kaynağı Kiti” (Örneğin; el kitabı ve bildiriler, bilgilendirme broşürleri, tanıtım ve eğitim videoları, uygunluk ölçeği ve sonuç önlemleri) olarak tasarlanmıştır (Mueser ve ark. 2006).

\section{Hastalık yönetimi ve iyileşme programının işleyişi}

Hastalık Yönetimi ve İyileşme Programı hastaların iyileşme hedeflerine ulaşmak için psikiyatrik hastalıklarını diğerleriyle işbirliği içinde daha etkin bir şekilde yönetme yeteneklerini geliştirmeyi amaçlayan kanıta dayalı bir müdahaledir (Mueser ve ark. 2013). Bu program kronik ruhsal hastalığı olan bireylerin yaşamları üzerindeki kontrolü yeniden kazanmak için kendi tedavilerinde nasıl aktif ve bilgili bir katılımcı olacaklarını öğrendikleri standartlaştırılmış, müfredat tabanlı bir müdahaledir (Gingerich ve Mueser 2010). Temel amacı; kronik ruhsal hastalığı olan kişileri, hastalıklarını yönetme konusunda yetkilendirmek, kişisel iyileşme hedeflerini belirlemelerini sağlamak ve bu hedeflere ulaşmalarını kolaylaştırmak için gerekli bilgi ve becerileri öğreterek hastalık yönetimine yardımcı olarak rehabilite etmektir (Mueser ve ark. 2006, Dalum ve ark. 2011, Gingerich ve Mueser 2010). $\mathrm{Bu}$ program bipolar bozukluk, depresyon ve şizofreni tedavisinde kullanılabilmektedir (Gingerich ve Mueser 2005).

Hastalık Yönetimi ve İyileşme Programı hastalığın öz-yönetimini öğretmek için deneysel olarak desteklenen Transteorik Model ve Stres-Yatkınlık Modelinin (Mueser ve ark. 2006) yanı sıra kontrollü çalışmaların gözden geçirilmesiyle HYI bünyesinde birleştirilen beş hastalık öz yönetim stratejisinin HYI'nin çekirdek bileşenlerini oluşturmasından kaynaklanmaktadır. Bu çekirdek bileşenler; ruhsal hastalıklar ve tedavi seçeneklerine ilişkin temel bilgi sağlayan "Psikoeğitim", günlük ilaç kullanımını yönetmek ve hastalara ilacı günlük rutinin bir parçası yapan stratejileri öğretmeyi kapsayan "Davranışsal rehberlik", hastalara önceki nükslerin tetikleyicilerini ve yaklaşmakta olan bir nüksün erken uyarı işaretlerini 
tanımayı öğreten "Nüksleri önleme” ve hastaların psikiyatrik semptomlarla başa çıkmadaki mevcut başa çıkma stratejilerini kullanımlarını artırmayı veya yeni stratejiler öğrenmelerini içeren "Başa çıkma becerileri eğitimi” dir (Mueser ve ark. 2006, Gingerich ve Mueser 2010).

Hastalık Yönetimi ve İyileşme Programı “Ruhsal hastalıklarda iyileşme” kavramının ve bu kavramın her bir hasta için ne anlama geldiğinin araştırılmasıyla başlar. Her hastanın iyileşme tanımına dayanarak kişisel hedefler belirlenir, hedefler daha küçük adımlara ayrılır ve daha sonra program boyunca sürdürülür. Daha sonra hastaların hedeflerine doğru ilerlemelerine yardımcı olmak için hastalara hastalık yönetimi ile ilgili spesifik bilgi ve beceriler öğretilir (Mueser ve ark. 2006, Gingerich ve Mueser 2010, Mueser ve ark. 2013). Bu hedefler "İyileşme yakıtı" olarak hizmet etmekte, hastaların hastalıkları hakkında pratik gerçekleri ve belirli semptomlarla başa çıkmak için gereken becerileri öğrenmeleri için motivasyon kaynağı olarak hizmet etmektedir. Hastalar HYİP oturumlarında yeni beceriler uygular ve uygulayıcılarla birlikte geliştirilen ev ödevlerini tamamlar (Bartholomew ve Kensler 2010). Hasta birey için önemli kişiler (Aile üyeleri, arkadaş vb.), hastanın onayıyla programa ve ev ödevlerine dahil olabilirler (Mueser ve ark. 2006). Bu süreçte sağlık profesyonelleri hastaların iyileşme hedeflerini belirlemelerine ve program süresince bunları değerlendirmelerine ve izlemelerine yardımcı olurlar (Färdig ve ark. 2012).

Hastalık Yönetimi ve İyileşme Programı uygulayıcıları; sosyal hizmet uzmanı, uğraşı terapisti,vaka yöneticisi, danı̧̧man, hemşire, psikolog olabilmektedir.HYİP bireyselveya grup halinde (Sekiz ya da daha az hasta gruplarında) profesyoneller ve hastalar için uygun herhangi bir yerde (Örneğin; toplum ruh sağlı̆̆ı merkezi, ıslah evi vb.) sağlanabilmektedir. Seanslar genellikle 3-12 ay boyunca haftada bir ya da iki oturum şeklinde gerçekleştirilebilmekte ve bir oturum 45-90 dk. sürmektedir. Oturum süresinin en kritik belirleyicisi, hastaların meşgul kalma ve ilgili materyalleri öğrenme yetenekleridir. Bazı hastalar, dikkat ve anlama problemleri veya şiddetli hastalık semptomları dolayısıyla 30 dakikadan daha fazla süre odaklanmakta zorlanabilir. Bu tür durumlarda seanslar haftada iki veya üç kez, 20-30 dk. gibi kısa oturumlar şeklinde de düzenlenebilmektedir (Gingerich ve Mueser 2010).

Hastalık Yönetimi ve İyileşme Programı kronik ruhsal hastalığı olan bireylerin sağlık profesyonelleriyle işbirliği yapmasına, hastalıklarına karşı duyarlılıklarını azaltmalarına ve hastalık semptomlarıyla etkin bir şekilde başa çıkmalarına yardımcı olacak beş özyönetim stratejisinden oluşur (Mueser ve ark. 2002). Bu beş strateji, 11 konu alanına ayrılarak HYİP'ye dahil edilmiştir. Bu konular, seanslar sırasında eğitimsel, motivasyonel ve bilişseldavranışçı ögretim stratejilerinin bir kombinasyonu kullanılarak öğretilir. Her modülün bir amacı, belirtilen müdahaleleri ve önerileri vardır. Her bir modül hastalar için eğitim broşürleri ve uygulayıcılar için öğretim kuralları dahil olmak üzere, modüller veya konuya ilişkin alanlar şeklinde düzenlenmiştir (Mueser ve ark. 2006, Gingerich ve Mueser 2010).

Hastalık Yönetimi ve İyileşme Programı'nın üçüncü versiyonu aşağıda belirtilen 11 modülü içermektedir (Mueser ve ark. 2013). Whitley ve ark. (2009) modülleri şöyle açıklamaktadır:

1. İyileşme Stratejileri: İnsanların iyileşmenin onlar için ne anlama geldiğini tanımlamalarına, iyileşme hedeflerini belirlemelerine ve bunları küçük adımlara bölmelerine yardimci olur. 
2. Ruhsal Hastalıklar ile İlgili Temel Bilgiler: Şizofreni, bipolar bozukluk ve majör depresyon hakkında bilgi sağlar. Teşhislerin nasıl yapıldığını, hastalık belirtilerini açıklar ve yaygınlık hakkında bilgi verir. Psikiyatrik bozukluğu olan ünlü insanlardan örnekler verir.

3. Stres-Yatkınlık Modeli: Tedavi için temel oluşturur. Psikiyatrik bozuklukların doğada biyolojik olarak nasıl oluştuğunu ve nasıl ortaya çıktığını açıklar. Hastalığın şiddeti ve seyrinin stresten etkilenebildiğine vurgu yapar ve biyolojik yatkınlık (Örneğin; ilaç almak, uyuşturucu ve alkolden uzak durmak) ve stresin etkilerini en aza indirmek için (Örneğin; başa çıkma stratejilerini öğrenmek ve sosyal desteği geliştirmek) stratejiler sağlar.

4. Sosyal Destek Oluşturma: Hastaların memnuniyetlerini sosyal destekleriyle değerlendirmelerine yardımcı olur, insanlarla tanışmak ve yakınlığı artırmak için kişisel ilişkilere ilişkin stratejiler geliştirilmesini sağlar. Hastaların ihtiyaç duydukları becerileri öğrenmelerine yardımcı olmak için sosyal beceri eğitimi tekniklerini kullanmalarını sağlar.

5. İlacı Etkili Kullanma: İlaçların rolü ve ilaç kullanımının hastalıktan iyileşmeye nasıl yardım edebileceği hakkında bilgi sağlar. İlaçların yararlarını ve yan etkilerini tartışır. Hastalara ilaçlarını günlük yaşamlarının rutin bir parçası olarak ele almaları için stratejiler kullanmayı ögretir.

6. Madde ve Alkol Kullanımı: Yaygın olarak kullanılan maddeler ve etkileri hakkında bilgi sağlar. Hastaların madde kullanımının genel sebeplerini tanımlar. Hastaların madde kullanmanın artılarını ve eksilerini keşfetmelerine yardımcı olur.

7. Nüksleri Azaltma: Gelecekteki nüksleri engellemek için hastaların geçmiş nükslerini incelemelerine yardımcı olur. Tetikleyicileri ve nüksün erken uyarı işaretlerini tanımlar. Hastaların kendi nüksetme önleme planlarını geliştirmelerine yardımcı olur. Hastaların nüks belirtilerini sağlık personeli ve diğer önemli kişilerle paylaşmalarına teşvik eder ve hastaların nüks önleme planlarının unsurlarını prova etmelerine yardımcı olur.

8. Stresle Başa Çıkma: Hastaların yaşamlarındaki stres kaynaklarını tanımasına ve stresörlere kendi fiziksel ve duygusal tepkilerini öğrenmesine yardımcı olur. Gevşeme teknikleri dahil stresle başa çıkma stratejilerini (Rahat nefes almayı, huzurlu bir sahneyi hayal etmeyi ve kas gevşetmeyi vb.) öğretir.

9. Kalıcı/Kronik Belirtilerle Başa Çıkma: Problem ve semptomlarla başa çıkmak için hastalara adım adım bir problem çözme yöntemi öğretir. Hastaların baş etmek için zaten kullandıkları becerileri tanımlamasına ve geliştirmesine yardımcı olur.

10. İhtiyaçların Davranışsal Sağlık Sisteminde Karşılanması: Servisler dahil olmak üzere ruh sağllğ̣ sistemine genel bir bakış sunar ve Toplum Ruh Sağlığ1 Merkezleri (TRSM) tarafından yaygın olarak sunulan programları (Örneğin; sosyal beceri eğitim grupları ve mesleki hizmetler) açıklar.

11. Sağlıklı Yaşam: Hastaların hak kazanabileceği finansal yardımları (Örneğin; sosyal güvenlik, engellilik geliri) ve sigorta yardımlarını açıklar. Ruh sağlığı sisteminde kendini savunması için stratejiler sağlar.

Hastalık yönetimi ve iyileşme programı seanslarında hastalara eğitimsel ve bilişsel davranış̧ı yaklaşımlar olmak üzere farklı stratejilerin birleşimi kullanılarak müfredat 
öğretilmektedir (Mueser ve ark. 2013). Seanslarda az bir eğitimsel teknik kullanılır. Bunlar; interaktif öğrenme, anlamanın/kavramanın kontrolü ve bilgiyi listelemekten herhangi biri olabilir. Ayrıca pekiştirme, davranış şekillendirme, modelleme, rol-oynama, bilişsel yeniden yapılandırma ve gevşeme eğitimi gibi bilişsel davranış̧̧ı tekniklerden en az biri de kullanılmaktadır (Gingerich ve Mueser 2010). Ayrıca oturumlarda hastaların davranışlarını değiştirmek için anlamlı nedenler bulmalarına ve iyileşmeleri için bir umut ve destek duygusu aşılanmasına yardımcı olmak için motivasyon teknikleri de kullanılmaktadır (Salyers ve ark. 2010). Programın oturumları standart bir yapı izlenmekte olup seansın yapılandırılmı̧ özeti aşağıdaki tabloda belirtildiği gibidir (Mueser ve ark. 2006, Gingerich ve Mueser 2010, Mueser ve ark. 2013).

Tablo 1. Bir hastalık yönetimi ve iyileşme programı seansının yapılandırılmış özeti

\begin{tabular}{|c|c|c|}
\hline HYIP seansının yapılandırılmış özeti & $\begin{array}{l}\text { Bireysel } \\
\text { format }\end{array}$ & $\begin{array}{l}\text { Grup } \\
\text { formatı }\end{array}$ \\
\hline $\begin{array}{l}\text { Sosyalleşme ve herhangi bir majör problemin belirlenmesi } \\
\text { Klinisyen ve hastalar/danışanlar bu süreyi, ilişki kurmak ve oturum sonunda ele alınması gereken ek sorunları } \\
\text { tartışmak için kullanırlar. }\end{array}$ & $1-3 \mathrm{dk}$ & $1-3 \mathrm{dk}$ \\
\hline $\begin{array}{l}\text { Önceki oturumların gözden geçirilmesi } \\
\text { Materyal, hastaların bilgi ve becerilerini anlamalarını ve hatırlamalarını değerlendirmek amacıyla önceki } \\
\text { oturumun içeriği gözden geçirilir. }\end{array}$ & $1-3 \mathrm{dk}$ & $1-3 \mathrm{dk}$ \\
\hline $\begin{array}{l}\text { Önceki oturumdan ev ödevinin gözden geçirilmesi } \\
\text { Ev ödevlerinin tamamlanmı̧ olup olmadığı gözden geçirilir, hastaların başarı çabaları ya da sonuç çıktıları } \\
\text { pekiştirilir ve karşılaşılan herhangi bir zorluk sağılık personeli ve hasta tarafından ortaklaşa çözümlenir. }\end{array}$ & 3-5 dk. & $5-10 \mathrm{dk}$ \\
\hline $\begin{array}{l}\text { Hedeflerin takibi } \\
\text { Hastaların kişisel hedeflerine yönelik ilerlemeleri değerlendirilir, engeller belirlenir ve bu sorunlar beraber } \\
\text { çözülür ve sonraki adımlar belirlenip planlanarak ya da yeni hedefler belirlenerek başarı süreci takip edilir. }\end{array}$ & $1-3 \mathrm{dk}$ & $5-10 \mathrm{dk}$ \\
\hline $\begin{array}{l}\text { Mevcut oturum gündemi ayarlanır } \\
\text { Oturumun geri kalanı için ortak bir gündem belirlenir. }\end{array}$ & $1-2 \mathrm{dk}$ & $1-2 \mathrm{dk}$ \\
\hline $\begin{array}{l}\text { Yeni materyaller öğretilir ve yeni stratejiler uygulanır } \\
\text { HYi programına ilişkin materyaller gözden geçirilir ve her hastanın okuma yeteneğine, ilgi alanlarına, önceki } \\
\text { bilgilerine ve hedeflerine göre hazırlanmış eğitimsel, motivasyonel ve bilişsel-davranışsal stratejilerin bir } \\
\text { kombinasyonu kullanılarak öğretilir. }\end{array}$ & $30-40 \mathrm{dk}$ & $20-25 \mathrm{dk}$ \\
\hline $\begin{array}{l}\text { Yeni ev ödevinin kararlaştırılması } \\
\text { Sağlık personelleri ve hastalar, oturumda öğretilen materyalleri gözden geçirmek ve uygulamak ya da } \\
\text { hastaların kişisel hedeflerine yönelik adımlar atmak için bir ev ödevi üzerinde anlaşır, tamamlanmalarını } \\
\text { engelleyebilecek herhangi bir engel öngörülüp görülmediği değerlendirilir ve mevcutta var olan bir engel } \\
\text { olması durumunda sorun giderilir. }\end{array}$ & $3-5 \mathrm{dk}$ & 5-10 dk. \\
\hline $\begin{array}{l}\text { Mevcut oturum sürecinin özetlenmesi } \\
\text { Oturumda ele alınan sorunlar gözden geçirilir ve hastaların geri bildirimleri alınır. }\end{array}$ & $3-5 d k$ & $3-5 d k$ \\
\hline
\end{tabular}

\section{Hastalık yönetimi ve iyileşme programı ile ilgili yapılan çalışmalar}

Mueser ve arkadaşları (2006) Avustralya'da ve ABD'de 25 şizofreni ve şizoaffektif bozukluğu olan hastada yapmış oldukları kontrolsüz pilot çalışmada 24 katılımcı programı ve 17 katılımcı ise üç aylık takip değerlendirmelerini tamamlamıştır. Tedavi 
sonrası katılımcıların, hastalık yönetimi ve iyileşme, iyileşme algısı ve küresel işlevsellik puanlarında artış olmuştur. Ayrıca psikopatolojide, işlevsellikte, öz yönetim aktivasyonu öz bildiriminde, yaşam kalitesi ve toplum yaşamında öz yeterlilik konusunda hastalar önemli gelişmeler göstermişlerdir.

Hasson-Ohayon ve arkadaşları (2007) grup formatında uygulanan HYİ'nin etkinliğini değerlendirmek amacıyla İsrail'deki 13 TRSM'de 210 hastayla yapmış oldukları randomize kontrollü çalışmada; müdahale öncesi ve sonrasında HYİP'deki hastaların sonuçlarında standart tedavi görenlere kıyasla anlamlı bir artı̧̧ olduğunu bildirmişlerdir. Her iki grupta da başa çıkmada belirgin bir artış görülmüş ve sosyal destekte bir değişiklik bulunmamıştır. Tedavi sonrası, HYİP grubundaki hastalar hastalık yönetimi ve iyileşme ölçeğinin hasta ve klinisyen versiyonlarından anlamlı derecede yüksek puanlar almışlardır. Bu çalışma HYİP’nin etkinliğini değerlendiren ilk randomize kontrollü çalışmadır.

Levitt ve arkadaşları (2009) HYİP'nin ruhsal hastalığa ve destekleyici barınma hizmeti alan kronik ruhsal hastalığı olan kişilerin fonksiyonel sonuçlarına etkilerini değerlendirmek amacıyla 104 psikiyatri hastasıyla yapmış oldukları randomize kontrollü çalışmada; hastalar deney ve kontrol grubuna atanmı̧ ve deney grubuna altı ay süreyle HYİP uygulanmıştır. Altı ayın sonunda yapılan değerlendirmeler öz bildirimler, kör olmayan klinik değerlendirmeler ve kör görüşme değerlendirmelerini içermektedir. Bu değerlendirmeler; hastalık yönetimi, semptomlar, psikososyal işlevsellik, hastaneye yatış ve bağımlılık alanlarını içermektedir. Programa atanan katılımcılar, hastalık yönetimi derecelendirmelerinde (Öz bildirim ve klinisyen değerlendirmelerinde), Kısa Psikiyatrik Değerlendirme Ölçeğinde görüşmeye dayalı semptom derecelendirmelerinde ve Kısaltılmış Yaşam Kalitesi Ölçeğinde görüşmeye dayalı psikososyal işleyiş oranlarında kontrol grubundan çok daha önemli ölçüde gelişmeler göstermiştir. Her iki gruptaki katılımcılarda hastalık semptomlarına ilişkin öz değerlendirmelerde ve çalışma süresince hastaneye yatış ve madde bağımlılığı oranlarında düşüş görülmüştür.

Roe ve arkadaşları (2009) bir yıl önce HYİP’yi tamamlamış 36 kronik ruhsal hastalığı olan bireyle görüşme tekniğini kullanarak yapmış oldukları nitel çalışmada şu sorulara yanıt aramışlardır: (1) Katılımcıların HYİP'yi tamamladıktan bir yıl sonra HYİ'yi etkili olarak algılayıp algılamadıklarını araştırmak ve açıklamak, (2) Eğer öyleyse, hangi alanlarda HYİP'yi faydalı bulduklarını araştırmak ve açıklamak, (3) Deneyimledikleri HYİ'nin hangi yollarla önceki rehabilitasyon müdahalelerinden farklı olduğunu araştırmak ve açıklamak. Görüşmelerin analizi ve temaları bağımsız olarak tanımlayan iki uzman tarafindan yapılmıştır. Araştırmada katılımcılar yüksek düzeyde algılanan yardımseverlik bildirmiş, HYİP'ye atfedilen üç gelişme alanı olarak; biliş, başa çıkma ve sosyal destek belirtmişlerdir. HYİP müdahalesinin benzersizliği ile ilgili olarak ise beş kategori ortaya çıkmıştır. Bunlar; yeni bilgiler öğrenme, sosyal destek, başa çıkma ve öz yönetim, program yapısı ve umut mesajıdir.

Salyers ve arkadaşları (2009) ABD'de 30 TRSM'de 324 psikiyatri hastasıla HYİ'nin ülke çapında uygulanmasını değerlendirmek amacıyla yapmış oldukları çalışmada altıncı ve 12. ay değerlendirmeleri sonucunda hastalarda hastalık özyönetimi ve umudun arttığ1 ve 
hizmet memnuniyetinin HYIP'den etkilenmediği saptanmıştır.

Whitley ve arkadaşları (2009) hangi faktörlerin hastalık yönetimi ve iyileşmenin başarılı bir şekilde uygulanmasını desteklediğini veya engellediğini incelemeyi amaçladıkları çalışmada; on iki toplum ruh sağlığı merkezinde, iki yıl boyunca HYİP’yi uygulamışlardır. Uygulamayı bir uygulama kaynak kiti ve bir danışman eğitmenle düzenli toplantılar ile desteklemişlerdir. Her merkezdeki uygulama çalışmaları iki yıl boyunca denetimli bir araştırmacı (Uygulamanın izleyeni) tarafindan izlenmiştir. Bu araştırmacı, her altı ayda bir kilit bilgi kaynaklarıyla kalitatif görüşmeler gerçekleştirmiş ve uygulamadaki ilerlemenin farkına varmak için sıklıkla rutin hasta gözlemleri yapmıştır. Bu nitel veriler, yazarlar tarafından, hastalık yönetimi ve iyileşme uygulamasının önündeki temel engelleri ve kolaylaştırıcıları ayırt etmek için incelenen bir veri tabanında toplanmıştır. Nitel verilerin içerik analizi yoluyla, uygulamanın başarısını veya başarısızlığını anlamlı bir şekilde belirleyen dört tema ortaya çıkmıştır. Bunlar liderlik, örgüt kültürü, eğitim, personel ve süpervizyondur. Bu temaların uygulamayı etkilemede sinerjik olarak çalıştığ sonucuna varılmıştır.

Fujita ve arkadaşlarının (2010) Japonya'da HYİP'nin uygulanabilirliğini ve sonuçlarını araştırdıkları çalışmada; şizofreni tanısı almış 35 hasta deney ve kontrol gruplarına atanmışlardır. Deney grubuna HYİP ve rutin tedavi programı kontrol grubuna ise yalnızca rutin tedavi programı uygulanmıştır. Hastalar semptom şiddeti, işleyişi, özyönetimde aktivasyon düzeyi, yaşam kalitesi, memnuniyet, toplum yaşamında öz yeterlik ve hizmetlerden memnuniyet açısından müdahale öncesi ve sonrasında değerlendirilmişlerdir. Deney grubuna uygulanan HYİP bireysel formatta bir ya da iki haftada bir 60-90 dakikalık oturumlarla sağlanmıştır. İki yıldan uzun bir süre içinde 25 hasta müdahaleyi tamamlamıştır. Ön test-son test karşılaştırmasında, deney grubundaki katılımcıların semptomlarda ve fonksiyonlarda, kişisel yönetimde, kendi kendine bildirilen aktivasyonda, yaşam kalitesi, memnuniyet ve toplum yaşamında öz yeterlilik açısından önemli iyileşmeler gösterdikleri bildirilmiştir.

Salyers ve arkadaşları (2010) kronik ruhsal hastalığı olan yetişkinler için iki kanıta dayalı uygulama olan Toplum Temelli Tedavi (TTT)-(Assertive Community Treatment-ACT) ve HYİP'yi bir araya getirerek bir çalışma yapmışlardır. Var olan dört ACT ekibinin ikisi rastgele seçilerek bir grup hastaya ACT uygulamak üzere diğer ikisi de rastgele seçilerek HYİP programını uygulamak üzere gruplara atanmışlardır. HYİP programına 47 hasta katılmıştır. Çalışmanın sonucunda ACT uygulanan hastaların sonuçlarında farklılık olmadığı ancak hastalık yönetimi ve iyileşme oturumlarına katılan hastaların hastane kullanımlarının azaldığı saptanmıştır.

Dalum ve arkadaşları (2011) tarafindan Danimarka Başkent Bölgesi'ndeki iki toplum ruh sağllğı merkezinde tedavi görmekte olan şizofreni ve bipolar bozukluk tanısıyla izlenen 200 hastada HYİP sonrası hastaların işlevsellik seviyelerini değerlendirmek amacıyla yapmış oldukları deneysel tasarımdaki (Randomize, değerlendirici-kör, çok merkezli) çalışmada; deney grubu dokuz ay HYİ'ye tabi tutulmuştur. Dokuzuncu ve 21. ayın sonunda değerlendirmeler yapılmıştır. Deney grubunda tedavi sonunda ve başlangıçtan 21 ay sonraki takipte işlevsellik düzeyinin arttığı, alkol/uyuşturucu kullanımının azaldığı, iyileşmenin 
bireysel anlamı ve umudun arttığı, hastaneye kabul ve poliklinik başvurusunun düştüğü belirtilmiştir.

Färdig ve arkadaşları (2011) İsveç'te altı psikiyatri polikliniği rehabilitasyon merkezinde tedavi görmekte olan 41 şizofreni veya şizoaffektif bozukluğu olan bireyde HYİP'nin semptomlar ve psikososyal işleyiş üzerindeki etkilerini değerlendirmek amacıyla yapmış oldukları çalışmada; deney grubundaki katılımcılar dokuz ay boyunca HYİP’ye dahil edilmiş, kontrol grubu ise standart tedavi almıştır. Değerlendirmeler başlangıçta, tedavi sonrası (dokuz ay) ve takipte (21 ay) hastalık yönetimi, psikiyatrik belirtiler, iyileşme, başa çıkma, yaşam kalitesi, hastaneye yatış, içgörü ve intihar düşüncesi gibi özbildirim ve klinisyen (Hem tedaviye hem de tedaviye kör olmayan) puanlamalarıyla yapılmıştır. Kör olmayan klinisyenlerin özbildirim raporları ve puanlamalarına göre deney grubundaki hastalar hastalık yönetiminde kontrol grubundaki katılımcılara göre önemli ölçüde daha fazla iyileşme göstermiştir. Psikoz Değerlendirme Aracını kullanan çalışmaya kör olarak atanan klinisyenler tarafından yapılan psikiyatrik semptom puanlandırmaları ve Başa Çıkma Anketlerinde bildirilen Psikososyal İşlevsellik Notları da kontrol grubuna göre anlamlı derecede yüksek sonuçlar göstermiştir.

Salyers ve arkadaşları (2011) HYİ'nin sağlık hizmeti kullanımına etkisini incelemek amaciyla 1 Temmuz 2003-30 Haziran 2008 tarihleri arasında Retrospektif Kohort tipte yapmı̧̧ oldukları çalışmada; HYI programını tamamlayan hastaların acil servis ziyaretinin ve hastaneye yatış günlerinin ACT alanlara göre daha az olduğunu saptamışlardır.

Färdig (2012) hastalıklarını daha iyi yönetmek ve iyileşmeyi teşvik etmek için şizofreni ve şizoaffektif bozukluğu olan hastalara eğitim vererek HYİP'nin etkinliğini incelemiş olduğu doktora tezinde; İsveç, Uppsala'daki altı psikiyatri polikliniğinde tedavi görmekte olan 41 hastayı deney ve kontrol grubuna ayırmış, deney grubundaki hastaları 40 seans HYIP'ye dahil etmiştir. HYİP'deki 21 katılımcıyı rutin tedavi gören 20 katılımcı ile karşılaştırmıştır. HYIP katılımcılarında, hastalığın öz yönetiminde daha fazla ilerleme, psikiyatrik semptomlarda azalma, başa çıkma becerilerinde azalma ve intihar düşüncesinde azalma olduğu saptanmıştır. Aynı çalışmada HYİP’yi tamamlayan 53 katılımcıda, nörobilişsel işlev ile hastalık yönetimi becerilerini edinme becerisi arasındaki olası ilişkiler incelenmiş; nörobilişsel zorlukların katılımcıların HYİ modeline göre hastalık yönetimini öğrenme firsatlarını etkilemediği sonucuna varılmıştır. Yine aynı çalışmada HYİP'nin sonucunda şizofreni semptomlarının şiddeti, programı tamamlayan 52 katılımcıda incelenmiştir. Sonuçlar, önemli ölçüde daha fazla katılımcının tedavi sonrası remisyon ciddiyet kriterini karşıladığını ve katılımcıların tedavi sonrası ciddiyet kriterine ulaşmadığını, HYİP'den de faydalandıklarını göstermiştir.

Thoreson'un (2012) kronik ruhsal hastalık tanısı alan bireylerin HYİP müfredatı için tedavi sonuçlarına ilişkin algılarını incelemek amacıyla yapmış olduğu nitel çalışmada; katılımcılar hastalık yönetimi ve iyileşme müfredatının, başa çıkma becerileri, özyönetim, sosyal işlevsellik, iyileşme sonuçları ve ikili iyileşme alanlarında tedavi sonuçları üzerinde olumlu bir etkiye sahip olduğunu belirtmiştir. Özellikle, olumlu sonuçlar olarak tanımlanan birbiriyle ilişkili yedi tema belirlenmiştir. Bunlar; eğitim, hedefler, iyileştirilmiş ruh sağllğ̣ istikrarı, kendi kendine değer artışı, iyileştirilmiş ilişkiler, daha fazla toplumsal katılım ve 
önceden var olan bilgilerdir.

Garber-Epstein ve arkadaşları (2013) HYİ uygulayıcılarının hasta sonuçları üzerindeki etkilerini incelemek amacıyla 210 TRSM hastasında yapmış oldukları çalışmada ruh sağlığı uzmanı, iyileşme rehberi ve mesleki yardımcıların HYİ uygulamalarının etkilerini incelemişlerdir. Çalışmada HYİ uygulayıcısının profesyonel geçmişine bakılmaksızın HYİ yeterli eğitim ve denetime sahip olan uygulayıcılar tarafından sunulduğunda iyi bir şekilde uygulanabileceğini ve olumlu sonuçlar üretebileceği sonucuna varılmıştır.

Bartholomew ve Zenchner (2014) bir Devlet Psikiyatri Hastanesi'nde HYIP'ye katılma saati ile taburcu olduktan sonra psikiyatrik geri kabul oranları arasındaki ilişkiyi incelemek amacıyla yapmış oldukları çalı̧̧mada; 1.186 arşiv verisi incelemiş ve HYI'nin her bir saati için hastaneye geri dönme riskinde \%1,1 oranında bir azalma olduğu belirtilmiştir.

Brummer ve Anne (2014) sağlık profesyonellerinin, ciddi ruhsal hastalığı olan bireylerle HYİyi kullanırken karşılaştıkları engelleri araştırmak amacı ile yaptıkları nitel çalışmada sağlık profesyonelleriyle yarı yapılandırılmış görüşme yapmışlardır. Çalışma sonucunda; karşılaşılan engellere ilişkin beş ana tema ortaya çıkmıştır. Bunlar; eğitim ve denetim, HYI ile zihinsel sağlık hizmetlerinin başlatılması, uygulayıcı ve hasta/danışan katılımı stratejileri, uygulayıcının rolü ve örgütsel destektir.

Salyers ve arkadaşları (2014) HYİ'nin etkinliğini değerlendirmek amaciyla yapmı̧̧ oldukları çalışmada; Gazi İşleri Anabilim Dalı Tıp Merkezi'nden ve TRSM'den 56'sı Gazi olan 118 şizofreni spektrum bozukluğu olan hastayı HYİ grubuna $(\mathrm{N}=60)$ veya haftalık problem çözme grup müdahalesine $(\mathrm{N}=58)$ atamışlardır. HYI grubundaki katılımcılar dokuz ay boyunca haftada bir kez bir araya gelmiştir. Klinik değerlendirmeler başlangıçta, dokuz ay ve 18 ay boyunca semptomların ölçülmesi, işleyişin, hastalığın öz yönetiminin, ilaç uyumunun, öznel iyileşme deneyimlerinin ve hizmet kullanımının değerlendirilmesi şeklinde yapılmıştır. Yapılan çalı̧̧ma sonucunda HYİ ile problem çözme grupları arasında anlamlı fark bulunmamıştır. Her iki gruptaki katılımcılar semptom şiddeti, hastalık yönetimi ve yaşam kalitesi bakımından zaman içinde önemli ölçüde ilerleme kat etmiş ve daha az acil servis ziyareti yapmışlardır. Her iki müdahaleye de katılım oranları düşük bulunmuştur. HYİ grubundaki katılımcıların \%28'i ve problem çözme grubundakilerin \%17'si programlanan grupların yarısından fazlasına katılmıs ve sırasıly \%23'ü ve \%34'ü hiçbir oturuma katılmamıştır. Ancak bu çalışma negatif bulguları bildiren ilk randomize kontrollü HYİ çalışmasıdır.

Beentjes ve arkadaşlarının (2015) E-HYİP için bir e-sağlık uygulamasının geliştirilmesini ve küme randomize kontrollü çalışmadaki etkisini değerlendirmek amacıyla yapmış oldukları çalışmada altı aşamalı elektronik geliştirme sürecinin sonunda HYİnin niteliksel değerlendirmesine dayalı olarak geliştirilen E-HYİ müdahalesi sonucunda deney grubunda özyönetim, iyileşme ve genel sağlı algısının arttığı görülmüştür.

Färdig ve arkadaşları (2016) HYİyi tamamlayan şizofreni veya şizoaffektif bozukluğu olan 53 hastada nörobilişsel işlevler ve hastalık öz-yönetim becerilerinin kazanılması arasındaki ilişkiyi incelemek amacıyla yapmış oldukları çalışmada nörobilişsel işlevler ve HYİP ile hastalık öz-yönetim becerileri kazanma arasında ilişki belirleyememişlerdir. 
Van Langen ve arkadaşları (2016) HYİyi tamamlayan kişilerin iyileşmeyi kendi bakı̧̧ açılarıyla nasıl tanımladıklarını ve iyileşmeyi geliştiren içerikleri belirlemek amacıyla Hollanda'da bir psikiyatri polikliniğinde HYİP'yi 13 ya da 19 ay önce bitirmiş, 14 şizofreni ya da psikotik hastalık tanısı almı̧̧ hastayla yapmış oldukları fenomolojik bir çalışmada; "Bir HYİP’ye katıldınız; bu programı nasıl deneyimlediniz?" ve “İyileşme sizin için ne ifade ediyor?" sorularına yanıt aramışlardır. Çalışma sonunda beş ana tema belirlenmiştir. Bunlar; hedef belirleme becerileri, semptom yönetimi becerileri, akran bilgilerini paylaşma, HYI'yi ders kitabından alma ve pratik becerileri öğrenme. Bu çalışma HYİP’nin kişisel iyileşmeyi nasıl geliştirdiği hakkında HYİ'yi tamamlayan şizofreni ya da psikotik hastalık tanısı almış kişilerin deneyimleri hakkındaki ilk fenomenolojik çalışmadır.

Tan ve arkadaşları (2016) semptomların azaltılması, yeniden hastaneye yatı̧̧ oranları ve sosyal işleyiş açısından mevcut bakım standardına göre etkinliğini değerlendirmek amacıyla deneysel tasarımda yapmış oldukları çalışmada deney grubundaki katılımcılar HYİP'ye tabii tutulurken, kontrol grubundaki katılımcılar 12 ay boyunca toplum psikiyatri hemşireleri tarafından standart bakım almışlardır. Deney grubundaki katılımcıların, daha düşük sayıda hastaneye başvuru yaptıkları, hastanede daha kısa süreli kalış süresine sahip oldukları, Kısa Psikiyatrik Değerlendirme Ölçeği puanlarının düştüğü ve ayrıca Hastalık Yönetimi ve İyileşme Ölçeği ve Küresel Değerlendirme Ölçeği puanlarının anlamlı derecede yükseldiği saptanmıştır.

Dalum ve arkadaşları (2018) şizofreni veya bipolar bozukluğu olan Danimarkalı hastalarda standart tedavi ile karşılaştırıldı̆̆ında HYİ'nin etkinliğini araştırmak amacıyla yapmış oldukları randomize kontrollü çok merkezli çalışmada; kontrol grubuna standart tedavi hizmeti sağlanırken, deney grubuna dokuz aylık süre boyunca haftada bir saatlik oturumlarla grup formatında HYİP uygulamışlardır. Araştırma sonunda HYİP'nin işlevsellik, semptomlar, madde kullanımı ve hizmet kullanımı üzerinde önemli bir etkisi olmadığı saptanmıştır.

Jensen ve arkadaşları (2019) HYİP’ye katılan şizofreni veya bipolar bozukluğu olan hastalarda müdahale sonrası ve bir yıllık takipte klinik-kişisel iyileşme ve hastalık yönetiminde gelişme olup olmadığını değerlendirmek amacıyla yaptıkları çalışmada; Danimarka'nın Başkent Bölgesi’ndeki üç toplum ruh sağlığı merkezindeki 198 hastayı çalı̧̧maya dahil etmişlerdir. Randomize kontrollü bu çalışmada deney grubu grup formatında HYIP ve standart tedavi alırken, kontrol grubu standart tedavi almıştır. Katılımcıların tüm sonuçları başlangıçta, müdahale sonrası ve bir yıllık takipte değerlendirilmiştir. Uzun vadeli sonuçlar klinik iyileşmeye (Yani semptomlar, global işleyiş ve hastaneye yatı̧̧) ve kişisel iyileşmeye (Yani umut ve kişisel iyileşme) göre sınıflandırılmıştır. HYİP alan girişim ve HYİP almayan kontrol grupları arasında, müdahaleden bir yıl sonra anlamlı bir fark bulunmamış ve semptomlar, hastaneye yatı̧s sayısı, acil servis ziyaretleri veya ayaktan tedavi sayıları arasında anlamlı bir fark bulunmamıştır. Mevcut HYİ’nin çalışmasının, bir yıllık takipte klinik ve kişisel iyileşme üzerinde önemli bir etki göstermediği saptanmıştır. 


\section{Tartışma}

İyileşme kavramı ruh sağlığı açısından oldukça önemli bir kavram olmasına rağmen sınırlarının çizilmeside bir o kadar güçtür. Bu durum son yıllarda ruh sağlı̆̆ı alanında “iyileşme" kavramı üzerinde yapılan tartı̧̧maların artışına yol açmıştır. Hastalık Yönetimi ve İyileşme iyileşme odaklı yaklaşımı temel alan bir program olarak tasarlanmış müfredat tabanlı bir psikiyatrik rehabilitasyon uygulamasıdır. ABD'de 2002 yılında ruh sağlı̆̆ 1 hizmet sunumunun geliştirilmesi için kurulan komisyonun 2003 yllında meşru bir tedavi amacı olarak iyileşme vizyonunun rehberliğinde ruhsal sağlık sisteminin kapsamlı bir dönüşüm yapması gerektiği yönünde bir çağrıda bulunmasının ardından konu ile ilgili stratejiler ve rehberlerde geliştirilmeye başlanmıştır. Bu kapsamda da HYİ'nin etkinliğini araştırmaya yönelik araştırmalar yapılmaya başlanmıştır. Bu bağlamda hastalık yönetimi ve iyileşme programı ile ilgili yapılan çalışma sonuçları gözden geçirildiğinde konu ile ilgili birbiri ile benzeşen ve benzeşmeyen farklı çalışma sonuçlarının olduğu görülmektedir.

HYİP'nin etkinliğinin değerlendirildiği çalışmalarda hastaların hastalık yönetimi ve iyileşme, iyileşme algısı ve küresel işlevsellik puanlarında, sosyal işlevsellikte, yaşam kalitesi, psikososyal işleyiş oranlarında, iyileşmede, memnuniyet ve toplum yaşamındaki öz yeterliliklerinde artış, psikopatolojide azalma (Mueser ve ark. 2006, HassonOhayon ve ark. 2007, Levitt ve ark. 2009, Fujita ve ark. 2010, Färdig ve ark. 2011, Dalum ve ark. 2011, Thoreson 2012), hastaların hastane kullanımında azalma ve daha az hastaneye yatış sayısı (Salyers ve ark. 2010, Dalum ve ark. 2011, Salyers ve ark. 2011, Bartholomew ve Zenchner 2014, Tan ve ark. 2016), alkol/uyuşturucu kullanımının azalması ve iyileşmenin bireysel anlamının ve umudun artışı (Dalum ve ark. 2011) hastalığın öz yönetiminde daha fazla ilerleme, psikiyatrik semptomlarda azalma, başa veçıkma becerilerinde artma ve intihar düşüncesinde azalma (Färdig 2012, Thoreson 2012), özyönetim, iyileşme sonuçları ve ikili iyileşme alanlarında artış (Thoreson 2012), E-HYİ müdahalesi sonucunda deney grubunda özyönetim, iyileşme ve genel sağlık algisında artma (Beentjes ve ark. 2015) olduğu bildirilmiştir. Bu bulguların aksine HYİP'nin etkinliğini değerlendirmek amacıyla yapılan diğer çalışmalarda nörobilişsel işlevler ve HYİP ile hastalık öz-yönetim becerileri kazanma arasında ilişki olmadığ 1 (Färdig ve ark. 2016), işlevsellik, semptomlar, madde kullanımı ve hizmet kullanımı üzerinde önemli bir etkisinin olmadığ1 (Dalum ve ark. 2018), semptomlar, hastaneye yatı̧̧ sayısı, acil servis ziyaretleri veya ayaktan tedavi sayıları arasında anlamlı bir fark bulunmadı̆̆ı da (Jensen ve ark. 2019) bildirilmektedir. Salyers ve arkadaşları (2014) HYİP'nin etkinliğini değerlendirmek amacıyla şizofreni spektrum bozukluğu olan hastalarla yapmış oldukları çalışmada bir gruba HYİP bir gruba da problem çözme becerisi uygulamışlardır. Yapılan çalışma sonucunda HYI ile problem çözme grupları arasında anlamlı fark bulunmadığı, her iki gruptaki katılımcıların semptom şiddeti, hastalık yönetimi ve yaşam kalitesi bakımından zaman içinde önemli ölçüde ilerlemeler kat ettikleri ve daha az acil servis ziyareti yaptıkları bildirilmiştir. Roe ve arkadaşları (2009) HYİP’yi tamamlamış 36 kronik ruhsal hastalığı olan bireyle görüşme tekniğini 
kullanarak yapmış oldukları nitel çalışmada katılımcılar yüksek düzeyde algılanan yardımseverlik bildirmiş, HYİP’ye atfedilen üç gelişme alanı olarak; biliş, başa çıkma ve sosyal destek, uygulamanın başarısını veya başarısızlı̆̆ını anlamlı bir şekilde belirleyen dört tema olarak ise liderlik, örgüt kültürü, eğitim, personel ve süpervizyonun ortaya çıktığını bildirmişlerdir. Konu ile ilgili yapılan çalışmalarda farklı araştırma sonuçlarının çıkmasının nedeni olarak uygulamaların farklı ruhsal hastalık gruplarında yapılmış olması, ölçümlerde kullanılan ölçeklerin farklılığı, uygulamanın yapıldığ alınan bireylerin kültürel özelliklerinden etkilenmiş olabileceği düşünülmüştür. HYİP ile ilgili olarak yapılan çalışmaların yeni uygulanmaya başlayan uygulamalar olması nedeni ile bu konuda daha fazla araştırmaların yapılmasına ve araştırmaların sonuçlarının meta analiz çalışmaları ve sistematik derleme ile sunulmasına ihtiyaç vardır.

\section{Sonuç}

Hastalık yönetimi ve iyileşme programı iyileşmenin bir süreç olduğuna odaklanan, birey merkezli, kişisel iyileşme vurgusu ön planda bir psikiyatrik rehabilitasyon uygulamasıdır. Yapılan çalışmalar doğrultusunda programın yatan hasta ve poliklinik tedavisinde başarıyla uygulanabileceğini söylemek mümkündür. Hastalık yönetimi ve iyileşme programının ruhsal hastalığın devam eden semptomlarının olup olmadığına bakılmaksızın kişilerin anlamlı ve tatmin edici bir yaşam ve kişisel kimlik oluşturmalarını ve sürdürmelerini desteklediği, dolayısıyla hastalık özyönetimine katkı sağladığı düşünüldüğünde ruh sağlı̆̆1 hizmetlerinin sunumunda uygulamanın bir parçası olabileceği ortadadır. Bu amaçla ruh sağlığ sağlık profesyonellerinin konunun öneminin farkına varmaları ve hastalık yönetimi ve iyileşme programının uygulanabilirliği için liderlik etmeleri ile toplumumuzun ruh sağlığının korunmasına ve hastaların kişisel iyileşmelerine katkı sağlayacakları düşünülmektedir.

\section{Kaynaklar}

Anthony WA (1993) Recovery from mental illness: The guiding vision of the mental health service system in the 1990s. Psychosoc Rehabil J, 16(4):11-23.

Bartholomew T, Kensler D (2010) Illness management and recovery in state psychiatric hospitals. Am J Psychiatr Rehabil, 13:105-125. Bartholomew T, Zenchner M (2014) The relationship of illness management and recovery to state hospital readmission. J Nerv Ment Dis, 202:647-650.

Beentjes TAA, van Gaal BGI, Goossens PJJ, Schoonhoven L (2015) Development of an e-supported illness management and recovery programme for consumers with severe mental illness using intervention mapping, and design of an early cluster randomized controlled trial. BMC Health Serv Res, 16:20.

Bilge A, Çam 0 (2002) Toplum ruh sağlğı hizmetlerinde rehabilitasyon ve hemşirelik. Sağlık ve Toplum Dergisi, 12(4):33-37.

Brummer JA (2014) Barriers of using illness management and recovery with adults with severe mental illness (Masters thesis). Saint Paul, Minnesota, St. Catherine University.

Dalum HS, Korsbek L, Mikkelsen JH, Thomsen K, Kistrup K, Olander M et al. (2011) Illness management and recovery (IMR) in Danish community mental health centres. Clinical Trial, 12:195.

Dalum HS, Waldemar AK, Korsbek L Hjorthoj C, Mikkelsen JH, Thomsen K et al. (2018) Illness management and recovery: Clinical outcomes of a randomized clinical trial in community mental health centers. PloS One, 13:e0194027.

Davidson L (2010) PORT through a recovery lens. Schizophr Bull, 36:107-108.

Färdig R (2012) IIIness Management and Recovery: Implementation and evaluation of a psychosocial program for schizophrenia and 
schizoaffective disorder (Doctoral thesis). Uppsala, Uppsala University.

Färdig R, Fredriksson A, Lewander T, Melin L, Mueser KT (2016) Neurocognitive functioning and outcome of the Illness Management and Recovery Program for clients with schizophrenia and schizoaffective disorder. Nord J Psychiatry, 70:430-435.

Färdig R, Lewander T, Melin L, Folke F, Fredriksson (2011) A randomized controlled trial of the illness management and recovery program for persons with schizophrenia. Psychiatr Serv, 62:606-612.

Fujita E, Kato D, Kuno E, Suzuki Y, Uchiyama S, Watanabe A et al. (2010) Implementing the illness management and recovery program in Japan. Psychiatr Serv, 61:1157-1161.

Garber-Epstein P, Zisman-llani Y, Levine S, David R (2013) Comparative Impact of professional mental health background on ratings of consumer outcome and fidelity in an Illness Management and Recovery Program. Psychiatr Rehabil J, 36:236-242.

Gingerich S, Mueser KT (2005) Illness management and recovery. In Evidence-Based Mental Health Practice: A Textbook. (Eds RE Drake, MR Merrens, DW Lynde):395-424. New York, NY, Norton.

Gingerich S, Mueser KT (2010) IIIness Management and Recovery Implementation Resource Kit (Revised ed.). Rockville, MD: Center for Mental Health Services, Substance Abuse and Mental Health Services Administration.

Göka E (2001) Ruh sağlığı hizmetlerinde organizasyon sorunları ve paradigma değişikliğine duyulan gereksinim-2: psikiyatrik hospitalizasyon ve rehabilitasyon. Erişim: http://www.tirerolgoka.20m.com, Erişim tarihi: 04.11.2020.

Hasson-Ohayon I, Roe D, Kravetz S (2007) A randomized controlled trial of the effectiveness of the illness management and recovery program. Psychiatr Serv, 58:1461-1466.

Jensen SB, Dalum HS, Korsbek L, Hjorthoj C, Mikkelsen JH, Thomsen K et al. (2019) Illness management and recovery: one-year followup of a randomized controlled trial in Danish community mental health centers: long-term effects on clinical and personal recovery. BMC Psychiatry. 19:65.

Leamy M, Bird V, Le Boutillier C, Williams J, Slade M (2011) Conceptual framework for personal recovery in mental health: systematic review and narrative synthesis. Br J Psychiatry, 199:445-452.

Levitt AJ, Mueser KT, Degenova J, Lorenzo J, Bradford-Watt D, Barbosa A et al. (2009) Randomized controlled trial of illness management and recovery in multiple-unit supportive housing. Psychiatr Serv, 60:1629-1636.

Liberman RP, Kopelowicz A, Smith TE (2000) Psychiatric rehabilitation. In Comprehensive Textbook of Psychiatry. (Eds BJ Sadock, WA Sadock). Baltimore, Lippincott Williams Wilkins.

Mueser KT, Corrigan PW, Hilton DW, Tanzman B, Schaub A, Gingerich S et al. (2002) Psychiatr Serv, 53:1272-1284.

Mueser KT, Deavers F, Penn DL, Cassisi JE (2013) Psychosocial treatments for schizophrenia. Annu Rev Clin Psychol, 9:465-497.

Mueser KT, Gingerich S (2002) IIIness Management and Recovery Implementation Resource Kit. Rockville, MD, Substance Abuse and Mental Health Services Administration, Center for Mental Health Services.

Mueser KT, Meyer PS, Penn DL, Clancy R, Clancy DM, Salyers MP (2006) The Illness Management and Recovery program: rationale, development, and preliminary findings. Schizophr Bull, 32(suppl 1):732-743.

New Freedom Commission on Mental Health (2003) Achieving the Promise: Transforming Mental Health Care in America. Final Report. DHHS pub no SMA-03-3832. Rockville MD, Department of Health and Human Services, 2003.

Öztürk MO, Uluşahin NA (2018) Ruh Sağlı̆ı ve Bozukluklan Kitabı. Ankara, Medikomat Basım-Yayıncılık.

Pektaş İ, Çam 0 (2002) Psikiyatrik rehabilitasyon ve hemşirelik. Ege Üniversitesi Hemşirelik Yüksekokulu Dergisi, 18:153-162.

Roe D, Hasson-Ohayon I, Salyers MP, Shlomo K (2009) A one year follow-up of illness management and recovery: Participants'accounts of its impact and uniqueness. Psychiatr Rehabil J, 32:285-291.

Salyers MP, Godfrey JL, MCGuire AB, Gearhart T, Rollins AL, Boyle C (2009) Implementing the illness management and recovery program for consumers with severe mental illness. Psychiatr Serv, 60:483-490.

Salyers MP, McGuire AB, Kukla M, Fukui S, Lysaker PH, Mueser KT (2014) A randomized controlled trial of illness management and recovery with an active control group. Psychiatr Serv, 65:1005-1011.

Salyers MP, McGuire AB, Rollins AL, Bond GR, Mueser KT, Macy VR (2010) Integrating assertive community treatment and illness management and recovery for consumers with severe mental illness. Community Ment Health J, 46:319-329.

Salyers MP, Rollins AL, Clendenning D, MCGuire AB, Kim E (2011) Impact of Illness Management and Recovery programs on hospital and emergency room use by Medicaid enrollees. Psychiatr Serv, 62:509-515.

Shepherd G, Boardman J, Slade M (2008) Making recovery a reality, Sainsbury Centre for Mental Health, London.

Slade M (2009) 100 Ways to Support Recovery: A Guide for Mental Health Professionals. London, Rethink Mental IIIness. 
Sundeen SJ (1998) Psychiatric rehabilitation. In Principles and Practice of Psychiatric Nursing, (Eds G Stuart, MT Laraia): 243:263. USA, Clarinda Comp.

Tan CHS, Ishak RB, Lim TXG, Marimuthusamy P, Kaurss K, Leong JY (2017) IIIness management and recovery program for mental health problems: reducing symptoms and increasing social functioning. J Clin Nurs, 26:3471-3485.

Thoreson A (2012) The outcomes of illness management and recovery on severe mental illness: a client's perspective. Journal of International Social Issue, 1:53-69.

Van Langen WJM, Beentjes TAA, van Gaal BG, Nijhuis-van der Sanden MWG, Goossens PJJ (2016) How the Illness management and recovery program enhanced recovery of persons with schizophrenia and other psychotic disorders: a qualitative study. Arch Psychiatr Nurs, 30:552-557.

Victorian Government Department of Health (2011). Framework For Recovery-Oriented Practice. Melbourne, Victorian Government Department of Health.

Wallace CJ (1993) Psychiatric rehabilitation. Psychopharrnacol Bull, 29:537-548.

Whitley R, Gingerich S, Lutz WJ, Mueser KT (2009) Implementing the Illness management and recovery program in community mental health settings: facilitators and barriers. Psychiatr Serv, 60:202-209.

Yıldız M (2004) Psikiyatrik rehabilitayon. In Bireyden Topluma Ruh Sağlığı (Ed I Sayıl):151-164. İstanbul, Erler Matbaacılık.

Yazarların Katkıları: Yazarlar çalışmaya önemli bir bilimsel katkı sağladıklarını ve makalenin hazırlanmasında veya gözden geçirilmesinde yardımcı olduklarını kabul etmişlerdir.

Danışman Değerlendirmesi: Dış bağımsız.

Çıkar Çatışması: Yazarlar çıkar çatışması bildirmemiştir.

Finansal Destek: Yazarlar bu çalışma için finansal destek almadıklarını beyan etmişlerdir.

Authors Contributions: The authors attest that they have made an important scientific contribution to the study and have assisted with the drafting or revising of the manuscript.

Peer-review: Externally peer-reviewed.

Conflict of Interest: No conflict of interest was declared by the authors.

Financial Disclosure: The authors declared that this study has received no financial support. 